\title{
Influence of Classical Music to Decrease Geriatric Anxiety Level
}

\author{
Agussalim*, Isak Tukayo and Frans Manangsang \\ School of Nursing, Health Polytechnic of Jayapura Indonesia
}

Submission: February 26, 2020; Published: March 05, 2020

*Corresponding author: Agussalim, School of Nursing, Health Polytechnic of Jayapura Indonesia, Jalan Padang Bulan 2, Jayapura, Indonesia

\begin{abstract}
Background: According to the elderly World Health Organization (WHO) is a group of people aged 60 years or older. Mental or psychic changes in the elderly can be an increasingly egocentric attitude, easy to suspect, grow stingy or greedy when having something. There are several types that can be used to reduce the anxiety of elderly like music which can be applied as interventions to alleviate anxiety. It has been proven that the music compiled by Bach, Mozart, and other Italian composers is the most effective in providing distraction effects in patients.

Method: the type of research used is Quasi experiments that have treatment or pre and posttest design.

Result: there is a very strong correlation as there is a decreased in anxiety levels in the elderly after given classical music therapy with a value of T-test of 0.001 .

Discuss: Classical music therapy can be given to elderly patients who are hospitalized or in a nursing home or elderly confound. It can be a reference material or a reference in providing intervention to elderly patients with anxiety disorders.
\end{abstract}

Keywords: Geriatric; anxiety; classical music therapy; elderly compound.

\section{Background}

According to the elderly World Health Organization (WHO) is a group of people aged 60 years or older. According to law of Ministry of Health No. 13 of 1998 about the welfare of the elderly in Chapter 1 of article 1 paragraph 2, the elderly is a person who reaches the age of 60 years and above. According to the World Health Organization (WHO), in 2015, the world population is 60 years or older, reaching 900 million. Today, there are 125 million people aged 80 years or older, in 2050, estimated to reach 2 billion people around the world. Nearly as many as 120 million people live alone in China, and 434 million are in this age group worldwide. In the Southeast Asian region the elderly population is $8 \%$ or about 142 million people. In 2000 the number of elderly around 5.3 million (7.4\%) Of the total population, and the year 2020 is estimated the number of elderly 28.8 million (11.34\%) of the total population (Ministry of Health, Republic of Indonesia, 2013).

Population of Indonesia by age group and gender, age group of 45-49 years the number of males 8,352,946 inhabitants while the number of women 8,304,021 inhabitants, age group of 5054 years the number of males 7,064,237 the number of female women 7,114,776 souls, Age group 55-59 years male number
$5,737,258$ Soul number female 5,719,813 soul, age group 60-64 year male number $4,247,245$ souls number of women $4,150,520$, age group 65-69 years male number 2,780,759 the soul number of women 2,962,002 people, the group age 70-74 years of male number $1,817,892$ total female population $2,145,584$, age group $>75$ year number of males 1,876,328 the number of women of 2,650,552 people (Ministry of Health, Republic of Indonesia, 2016).

Population in Papua according to the population of productive age (15-64 years) based on the gender of males 1,164,235 people, whereas women 1,024,135 people with a total of 2,188,370 inhabitants. The population of nonproductive age ( $>65$ years) males is 28,115 while females are 21,444 people with a total of 49,559 people. (Center for Data and information, Ministry of Health, 2016).

Mental or psychic changes in the elderly can be an increasingly egocentric attitude, easily suspicious, increased stingy or greedy when having something (Nugroho, 2012). The most common psychological changes that occur and are most commonly experienced by the elderly are anxiety, depression, insomnia and dementia (Maryam, 2011). Anxiety is an emotional state 
that does not have a specific object, in the form of an obscure worry, spreading, relating to the uncertain and helpless feelings of Fear (Stuart, 2006) Anxiety is an unclear feeling of fear and Not supported by the situation. Anxiety disorders are not considered part of the normal aging process, but the changes and challenges that elderly often face (such as chronic diseases, cognitive disorders, emotional disorders) may contribute to the development of symptoms and disorders Anxiety (Touhy, 2014).

Basically all types of music can actually be used in an effort to lower the anxiety level (Campbell, 2006). There are several types of music that can be applied as interventions to reduce anxiety, among others Music Cure, Mozart's classical music, classical music's Four Seasons, classical music played along with natural sounds (sea sounds, rain, and water sounds) as well as other classical music that has been extensively researched by researchers (Analyia \& Moekroni, 2016; Heijden, Araghi, Dijk, Jeekel \& Hunink, 2015; Mohammadi, Ajorpaz, Torabi, Mirsane \& Moradi, 2014; Trappe, 2012). However, it is often recommended to select music with a tempo of about 60 beats / minutes so that the optimal resting state is obtained [1].

The most useful music for a patient's health is classical music. It has been proven that the music compiled by Bach, Mozart, and other Italian composers is the most effective in providing distraction effects in patients (Trappe, 2012). This is in line with the research conducted by Muhammad Luqman Prihananda \& Arina Maliya (2011) entitled "Effect of classical music therapy on the anxiety level of hemodialysis patients at the PKU Muhammadiyah Hospital of Surakarta", indicating the influence of classical music therapy to the anxiety level in hemodialysis patients in hospital pku Muhammadiyah Surakarta. The selection of classical music is based on the belief of many experts that the rhythm and tempo of most classical music follows a human heart rate speed of about 60 beats / minutes (Campbell, 2006). Patients who receive the most benefit from classical music therapy include patients with anxiety, depressive syndrome, and cardiovascular disorders and those suffering from painful, stress or sleep disorders.
Based on the above background, researchers are interested to do research to the elderly who live in the elderly compound in Sentani District of Jayapura Regency to learn about the effect of giving classical music therapy to elderly anxiety level [2].

\section{Statement of the problem}

Based on the background of the problem above, the problem of this research is "is there any influence of classical music therapy to the level of elderly anxiety in the home of the elderly compound in Jayapura district?"

\section{Method of Research}

The type of research used is research quasi experiments that have treatment. The research aims to reveal causal relationships by involving control groups in addition to experimental groups, but the selection of the two groups is not random. The research also aims to clarify the cause of an event or both. With the design used is a pre and post-Test control group design.

\section{Result}

Based on analysis data and test statistic carried out so that the following results are described in the form of analysis of univariate and bivariate

\section{Univariate analysis}

1. Data degree of anxiety when Pretests and posttest on group treatment

The table above shows that of the 21 respondents in the treatment group when the pretests experienced the "severe anxiety" category there are 14 elderly and the "mild anxiety" category there are 7 elderly with the highest score of 38 and a score of 22. After the treatment was given the music therapy, the anxiety category during posttest in the treatment group slightly decreased with "severe anxiety" 1 elderly, "mild anxiety" 20 elderly with the highest score of 29 and the lowest score of 18 (Table 1).

Table 1: Anxiety category Data on group treatment.

\begin{tabular}{|c|c|c|c|c|c|}
\hline \multirow{2}{*}{ No } & \multirow{2}{*}{ Respondents } & \multicolumn{2}{|c|}{ Pretest } & \multicolumn{2}{|c|}{ Posttest } \\
\hline & & Score & Information & Score & Information \\
\hline 1 & Miss. E. T & 29 & Severe & 19 & Mild \\
\hline 2 & Miss. H. R & 30 & Severe & 20 & Mild \\
\hline 3 & Miss. D. R & 29 & Severe & 19 & Mild \\
\hline 4 & Mr. F. N & 22 & Severe & 21 & Mild \\
\hline 5 & Miss. L. S & 29 & Severe & 20 & Mild \\
\hline 6 & Mr.Darius & 31 & Severe & 21 & Mild \\
\hline 7 & Mr. A. T & 25 & Mild & 18 & Mild \\
\hline 8 & Miss. A.N & 31 & Severe & 20 & Mild \\
\hline 9 & Miss. J. I & 29 & Severe & 20 & Mild \\
\hline 10 & Miss. B. T & 33 & Severe & 20 & Mild \\
\hline
\end{tabular}




\section{Anatomy Physiology \& biochemistry international journal}

\begin{tabular}{|c|c|c|c|c|c|}
\hline 11 & Miss. E. B & 29 & Severe & 18 & Mild \\
\hline 12 & Miss. Y. C & 35 & Severe & 20 & Mild \\
\hline 13 & Miss. D. L & 33 & Severe & 22 & Mild \\
\hline 14 & Miss. A. V & 26 & Mild & 22 & Mild \\
\hline 15 & Mr. M. S & 30 & Severe & 20 & Mild \\
\hline 16 & Mr. A. N & 22 & Mild & 19 & Mild \\
\hline 17 & Miss. R. D & 30 & Severe & 21 & Mild \\
\hline 18 & Mr. Y. F & 27 & Mild & 19 & Mild \\
\hline 19 & Miss. A. A & 26 & Mild & 25 & Mild \\
\hline 20 & Miss. L. R & 38 & Severe & 29 & Severe \\
\hline 21 & Miss. L. T & 25 & Mild & 18 & Mild \\
\hline
\end{tabular}

2. Data level of anxiety during pretests and posttest in control group

The table above shows that of 21 respondents in the control group when Pretests experienced the "severe anxiety" category there are 5 elderly and "mild anxiety" there are 16 elderly with the highest score of 37 and the lowest score 23. Without treatment is music therapy, anxiety categories during posttest in the average control group did not suffer a decline with the category of "severe anxiety" 3 elderly, "mild anxiety" 18 elderly with the highest score of 34 and the lowest score 19 (Table 2).

Table 2: Anxiety Data on the control group.

\begin{tabular}{|c|c|c|c|c|c|}
\hline \multirow{2}{*}{ No } & \multirow{2}{*}{ Respondents } & \multicolumn{2}{|c|}{ Pretest } & \multicolumn{2}{|c|}{ Posttest } \\
\hline & & Score & Information & Score & Information \\
\hline 1 & Miss. R. K & 33 & Severe & 30 & Severe \\
\hline 2 & Miss. S. W & 25 & Mild & 25 & Mild \\
\hline 3 & Miss. C. R & 23 & Mild & 19 & Mild \\
\hline 4 & Mr. T. S & 24 & Mild & 23 & Mild \\
\hline 5 & Miss. A. E & 27 & Mild & 24 & Mild \\
\hline 6 & Miss. Y. N & 26 & Mild & 26 & Mild \\
\hline 7 & Miss. B. K & 29 & Severe & 29 & Severe \\
\hline 8 & Miss. A. K & 25 & Mild & 25 & Mild \\
\hline 9 & Miss. R. H & 27 & Mild & 27 & Mild \\
\hline 10 & Miss. D. L & 24 & Mild & 24 & Mild \\
\hline 11 & Mr. A. G. T & 34 & Severe & 32 & Severe \\
\hline 12 & Mr. B. M & 25 & Mild & 22 & Mild \\
\hline 13 & Miss. S. K & 28 & Mild & 28 & Mild \\
\hline 14 & Miss. R. M & 24 & Mild & 24 & Mild \\
\hline 15 & Mr. G. T & 28 & Mild & 21 & Mild \\
\hline 16 & Miss. B. B & 37 & Severe & 35 & Severe \\
\hline 17 & Miss. A. T. A & 28 & Mild & 27 & Mild \\
\hline 18 & Mr. A. S & 26 & Mild & 26 & Mild \\
\hline 19 & Miss. E. R & 25 & Mild & 25 & Mild \\
\hline 20 & Mr. R. 0 & 32 & Severe & 30 & Severe \\
\hline 21 & Miss. R. N & 27 & Mild & 27 & Mild \\
\hline
\end{tabular}

Data level of anxiety group treatment and control group when pretests

Based on the above table shows that the subject in the treatment group is in severe anxiety as much as 14 people
(66.65\%) and was in mild anxiety as much as 7 people (33.3\%), while in the control group who were in severe anxiety as much as 5 people $(23.8 \%)$ and was in mild anxiety as much as 16 people (76.2\%) (Table 3). 
Table 3: Source: Primary Data 2019.

\begin{tabular}{|c|c|c|c|c|c|c|}
\hline \multirow{2}{*}{$\begin{array}{c}\text { Level } \\
\text { of } \\
\text { anxiety }\end{array}$} & \multicolumn{2}{|c|}{$\begin{array}{c}\text { Intervention } \\
\text { group }\end{array}$} & \multicolumn{2}{c|}{ Control group } & \multicolumn{2}{|c|}{ Total } \\
\cline { 2 - 7 } & $\mathbf{n}$ & $\mathbf{\%}$ & $\mathbf{n}$ & $\mathbf{\%}$ & $\mathbf{n}$ & $\mathbf{\%}$ \\
\hline Severe & 14 & 66.7 & 5 & 23.8 & 19 & 45.24 \\
\hline Mild & 7 & 33.4 & 16 & 76.2 & 23 & 54.76 \\
\hline Total & 21 & 100 & 21 & 100 & 42 & 100 \\
\hline
\end{tabular}

\section{Data level of anxiety group treatment and group} control during posttest

According to the table, it is known that the overall 21 subjects of the treatment group were given treatment of classical music therapy that was in severe anxiety as much as 1 person (4.76\%) And that is in mild anxiety as much as 20 people (95.24\%), while the level of anxiety in the control group without being given the classical music therapy treatment of the whole subject of the control group that was in severe anxiety as much as 4 people $(19.04 \%)$ And that was in mild anxiety as much as 17 people (80.95\%) (Table 4).

Table 4: Source: Primary Data 2019.

\begin{tabular}{|c|c|c|c|c|c|c|}
\hline \multirow{2}{*}{$\begin{array}{c}\text { Level } \\
\text { of } \\
\text { anxiety }\end{array}$} & \multicolumn{2}{|c|}{$\begin{array}{c}\text { Intervention } \\
\text { group }\end{array}$} & \multicolumn{2}{c|}{ Control group } & \multicolumn{2}{|c|}{ Total } \\
\cline { 2 - 7 } & $\mathbf{n}$ & $\%$ & $\mathbf{n}$ & $\%$ & $\mathbf{n}$ & $\%$ \\
\hline Severe & 1 & 4.76 & 4 & 19.04 & 5 & 11.90 \\
\hline Mild & 20 & 95.24 & 17 & 80.95 & 37 & 88.1 \\
\hline Total & 21 & $100 \%$ & 21 & $100 \%$ & 42 & 100 \\
\hline
\end{tabular}

\section{Bivariate analysis}

\section{Normality Test}

Testing the normality of data distribution in this study is using the Shapiro-Wilk method. Test data normality is intended to determine the normality of the research data spread. Data normality test calculation results can be seen in the table below

The (Table 5) shows the results of the test Shapiro-wilk normality which results in the value of a pretests variable of 0.012 and a posttest variable of 0.03 where the sig value is less than 0.05 . This indicates that the pretests or posttest data is a normal distribution $(p>0.05)$. Hypothesis testing for normal distribution data using alternative tests of coupled T tests is Wilcoxon's nonparametric test [3].

Table 5: Result of Normality Test

\begin{tabular}{|c|c|c|c|c|}
\hline \multirow{2}{*}{ Variable } & \multicolumn{4}{|c|}{ Shapiro- wilk } \\
\cline { 2 - 5 } & $\mathbf{N}$ & Statistic & df & Sig \\
\hline Pre test & 42 & 0,92 & 42 & 0.012 \\
\hline Post test & 42 & 0,929 & 42 & 0.003 \\
\hline
\end{tabular}

\section{Hypothesis testing}

The hypothesis test used in this study was test-T, since the study tested two unpaired samples. This test was inserted to see the classical effect of music therapy before and after the treatment is also seen the differences in the influence of classical music therapy in the group treatment with control group to the level of anxiety in the elderly (Table 6).

Table 6: The results of anxiety comparison before \& after treatment to the intervention group.

\begin{tabular}{|c|c|c|c|c|c|}
\hline \multicolumn{2}{|c|}{ Group } & n & $\begin{array}{c}\text { mean } \\
\text { rank }\end{array}$ & p-value & Information \\
\hline $\begin{array}{c}\text { Anxiety } \\
\text { before } \\
\text { intervention }\end{array}$ & $\begin{array}{c}\text { Negative } \\
\text { rank }\end{array}$ & 0 & 0 &, 000 & \\
\hline $\begin{array}{c}\text { Anxiety } \\
\text { after } \\
\text { intervention }\end{array}$ & $\begin{array}{c}\text { positive } \\
\text { rank }\end{array}$ & 21 & 11 & significant \\
\hline
\end{tabular}

To make a decision whether a proposed hypothesis is received or rejected, it is defined as follows: Ho is no influence of classical music therapy before and after treatment is also a difference in the influence of classical music therapy on group treatment with control group to the level of anxiety that occurs in the elderly compound in the district of Jayapura, Ha that there is the influence of classical music therapy before and after given treatment also differences of influence Classical music therapy in a group treatment with a control group to the level of anxiety that occurs in the elderly compound in Sentani Jayapura District. The hypothesis test decision making criteria by comparing the probability value (p) to $\alpha=5 \%$. The criteria of the decision are as follows: (1) when p > 0.05 then Ho is accepted and Ha is rejected; (2) When P is < 0.05 then Ho is rejected and Ha is accepted. The overall hypothesis test results are summarized and presented as follows

T-test results indicate that the $\mathrm{P}$ value obtained is 0.000 . The value turns out to be $<0.05$, thus Ho is rejected and Ha accepted. This means there is a significant difference in classical music therapy between anxieties before the group treatment with anxiety after the group's treatment of the elderly. Based on the research statistic data, positive rank or difference (positive) between the anxiety before the treatment group and after the treatment group is 0 positive data on the value $n$ and the mean rank that does not occur increased anxiety on seniors who are given classical music therapy. While negative rank (negative) between before the treatment group and after treatment group is 21 at the value $\mathrm{N}$ and 11 in the mean rank which means there has been decreased or reduction of anxiety in the elderly who are given music therapy Classic (Table 7).

Table 7: The results of anxiety comparison before \& after treatment to the intervention group.

\begin{tabular}{|c|c|c|c|c|c|}
\hline \multicolumn{2}{|c|}{ Group } & n & $\begin{array}{c}\text { mean } \\
\text { rank }\end{array}$ & p-value & Information \\
\hline $\begin{array}{c}\text { Anxiety } \\
\text { before } \\
\text { intervention }\end{array}$ & $\begin{array}{c}\text { Negative } \\
\text { rank }\end{array}$ & 4 & 11 & \multirow{2}{*}{, 036} & significance \\
\hline $\begin{array}{c}\text { Anxiety } \\
\text { after } \\
\text { intervention }\end{array}$ & $\begin{array}{c}\text { positive } \\
\text { rank }\end{array}$ & 17 & 4 & & \\
\hline
\end{tabular}




\section{Anatomy Physiology \& biochemistry international journal}

The result of $\mathrm{T}$ test shows that the value of $\mathrm{P}$ obtained is 0.036 the value is more than 0.05 , thus Ho accepted and Ha rejected. This means there is a significant difference in classical music therapy against anxiety before intervention into the control group with anxiety after intervention to the control group. Based on the research statistic data, positive rank or difference (positive) between the anxiety before the control group and after the control group is 0 positive data on the value $n$ and the mean rank that does not change of anxiety in the elderly which is given classical music therapy [4].

The result of $\mathrm{T}$ test shows that the value of $\mathrm{P}$ is 0.001 . The value was apparently less than 0.05 , thus Ho was rejected and Ha was accepted. This means there is a significant difference in classical music therapy between anxieties after a group intervention with anxiety after treatment of the control group (Table 8).

Table 8: Comparative results of anxiety to the intervention and contro group.

\begin{tabular}{|c|c|c|c|c|}
\hline Group & $\mathbf{n}$ & $\begin{array}{c}\text { mean } \\
\text { rank }\end{array}$ & p-value & Information \\
\hline $\begin{array}{c}\text { Anxiety before } \\
\text { intervention }\end{array}$ & 14 & 1.92 & \multirow{2}{*}{, 001} & significance \\
\hline $\begin{array}{c}\text { Anxiety after } \\
\text { intervention }\end{array}$ & 1 & 20.79 & & \\
\hline
\end{tabular}

\section{Discussion}

The research aims to determine the effect of classical music therapy on the level of anxiety in the elderly compound. Based on the results of the research gained that the characteristics of anxiety when pretests and posttest and at the treatment group showed that of 21 respondents in treatment groups when pretests experienced the category of "severe anxiety" there are 14 respondents and the category of "mild anxiety" there are 7 respondents with the highest score of 38 and a score of less 22 . After given the treatment is music therapy, the anxiety category during posttest in the treatment group experienced a decline with "severe anxiety" 1 respondent, "mild anxiety" 20 respondents with the highest score of 29 and the lowest score 18.

Anxiety characteristics when pretests and posttest in the control group show that of 21 respondents in the control group when Pretests is experiencing "severe anxiety" category there are 5 elderly and "mild anxiety" there are 16 elderly with scores The highest of the 37 and the lowest score 23 . Without treatment is music therapy, anxiety categories during posttest in the average control group did not suffer a decline with the category of "severe anxiety" 3 elderly, "mild anxiety" 18 elderly with the highest score of 34 and the lowest score 19. Similar results correspond to the research of Dina (2017) stating that with classical music therapy treatment the category of anxiety in the elderly when posttest was decreased.

Based on the results of research that can be from the test analysis of T-test shows that the value of significance is 0.001 .
The test result showed smaller than 0.05 . This means there is a significant difference in music therapy between the group treatment and the control group against anxiety. The elderly is a person aged 60 and above both men and women, who are still active in activity and work or those who are powerless to make their own living so that it depends on others to live themselves. The elderly is the process of gradually disappearance of the network's ability to repair itself or replace, maintain its normal functioning so that it cannot withstand infections and repair damages.

Mental or psychic changes in the elderly can be an increasingly egocentric attitude, easily suspicious, increased stingy or greedy when having something (Nugroho, 2012). The most common psychological changes that occur and are most commonly experienced by the elderly are anxiety, depression, insomnia and dementia (Maryam, 2011). It can be proved by the results of this study which suggests that elderly can experience anxiety with varying levels of anxiety whether it is mild anxiety as well as severe anxiety [5].

Many ways can be used to handle the anxiety of one of them by listening to music. According to Hawari (2011:53) Relaxation, eating chocolate, sleep can restore all physical and mental fatigue; in addition to that anxiety treatment can be done by listening to music. Music therapy includes one of the handles in treating stress and anxiety (Aizid, 2011:42). The music affects the decline in sympathetic nerve control, decreased heart rhythm, respiratory rate, metabolism, oxygen consumption and muscle tension. Listening to classical music helps in reducing stress, while listening to rock music enhances the rhythm of the Heart (John et al, 2010:75).

Similar research also conducted by Kartinah (2013) said that the analysis comparing the results before the therapy (pretest) and after therapy (posttest) showed the influence of music therapy on changes in the level of anxiety in the elderly. For some respondents classical music has tones that can make the heart comfortable when hearing it. Based on the results, there was a difference in the level of anxiety influence in the treatment group with the control group because most of the respondents were very interested in classical music, and when respondents experienced the respondent's anxiety Do choose to listen to music and do other activities to reduce its level of jealousy [6-8].

\section{Summary}

Based on the results of the research and discussion that has been previously exposed, it can be concluded that the elderly tend to experience high anxiety or weight due to the effects of aging and psychological distress because they are far from the family. The conditions of those living in the home and away from the family will trigger for them to experience anxiety disorders. With this research apparently provides an accurate solution to the elderly to prevent or overcome their anxiety disorder with classical music therapy about 15 minutes each time with a frequency twice daily. 


\section{Acknowledgements}

We are grateful for Ministry of Health of Indonesian Republic because he is wise so the research can be done smoothly.

\section{Funding}

The author(s) received no financial support for the research authorship, and/or publication of this article.

\section{Declaration of Conflicting Interests}

The authors declared no potential conflict of interest with respect to the research, authorship, and/or publication of this article.

\section{References}

1. Campbell D (2006) Music: Physician for Times to Come (3rd ed.) Wheaton: Quest Books.

2. Djohan (2009) Music psychology. Bandung: Best Publisher.
3. Djohan (2006) Music therapy, Theory and application. (LL Hidajat, Ed.) (1st ed). Galang press, Yogyakarta, Indonesia.

4. Hayati Farhatun (2017) The influence of classical music to anxiety levels in Monopause women in Pisangan area, Ciputat Timur, South Tangerang". [Skripsillmiah]. Universitas Hidayahtullah, Jakarta, Indonesia.

5. Ministry of Health Indonesian Republic. 2016, Indonesia Health Data profile, Depkes RI, Jakarta.

6. Mahatidanar Andika (2016) "The influence of classical music to decrease blood pressure in elderly patients with hypertension". [Skripsi Ilmiah]. UL, Bandar Lampung, Indonesia.

7. Safarta T, Saputra Eka N (2009) "Emotional Management" (1, Ed.). Bumi Aksara, Jakarta, Indonesia.

8. Simbolon P (2015) "Effect of music therapy on anxiety levels in patients with Pre-surgery in Santa Elisabeth Hospital nursing Room". [Skripsi Ilmiah]. Tahun, Medan, Indonesia.

\section{Your next submission with Juniper Publishers} will reach you the below assets

- Quality Editorial service

- Swift Peer Review

- Reprints availability

- E-prints Service

- Manuscript Podcast for convenient understanding

- Global attainment for your research

- Manuscript accessibility in different formats ( Pdf, E-pub, Full Text, Audio)

- Unceasing customer service

Track the below URL for one-step submission

https://juniperpublishers.com/online-submission.php 